Aliyev B.A., Alizadeh J.S.

DOI: 10.25108/2304-1730-1749.iolr.2018.57.6-19

\title{
The concept of ethnic extremism and its causes
}

\begin{abstract}
Stratification of the world community in modern times is still going on. Dynamic changes occurring in the world during the current period have impeded the integration of modern structures in all social spheres. Extremism and terrorism are the ideologies that divide the whole world of humanity from one another to the other, to discuss them with each other, and to engage in enmity sowings that will not lead to dialogue.
\end{abstract}

Keywords: extremism; ethnic extremism; causes of ethnic extremism; ethnos.

If we look at the literal meaning of extremism, we can see that this word originated in antiquity. Thus, the ancient Greek philosopher Aristotle used the word 'eschatos' to describe events contradicting stability. Later, this word was translated into Latin and used as 'extremis' and used to describe the most remote location. For example, the Latin term 'extremitas mundi' means 'the boundary of the world'.

Over time, the meaning of this word has changed and the expression has received more new players. For example, after 1945, the concept of 'extremism' was formally dictated by extreme right and left. From the 70s of the last century, this word has been used against antidemocratic political forces that are denying the current political regime and social structure, making use of violence instead of constructive dialogue, trying to create a society that challenges terror and violence.

\footnotetext{
- Aliyev Bakhtiyar Abdurahman oglu - PhD in Law, Associate Professor, Head of the Department of "Legal Support of State Security" of the Institute of Law and Human Rights of ANAS (Azerbaijan). Email: antiterror-baku@mail.ru

Alizadeh Javid Shirzad oglu - scientific worker of the Department "Legal Support of the State Security" of the Institute of Law and Human Rights of ANAS (Azerbaijan). E-mail: cavid6455@ mail.ru
} 
Extremism is a commitment to one's own ideas or beliefs, denying acceptance in society [5].

So today, the term extremism is used to refer to extreme ideas, political groups and organizations that are trying to challenge the conflict, terrorism, strife and disorder. Thus, the biggest difference of extremism from radicalism in the political and scientific sense is the implementation of extreme ideas by violent methods. The philosophical analysis of the term 'extremism' enables us to see and update new aspects of the old problem. The philosophical analysis of the term 'extremism' enables us to see and update new aspects of the old problem. Extremism is an obligation of individuals, groups, organizations, where radical views, positions are reflected. Extremism also affects social psychology, social psychology, morality, ideology, and so on. They arise between them. It should be noted that more extremism is described in social groups as 'social extremism', 'ethnic or national extremism' in ethnic groups, as 'political extremism' in public associations and political parties. There are various reasons for creating extremism, as follows:

- superiority of ideological interests;

- the desire to turn into social groups and the dissatisfaction with the actual situation;

- creation of anti-government activities.

Ethnic extremism is a form of extremism, and political events and processes occurring in the modern world and international conflicts affect the world. Each person belongs to a specific nation. There is no nation without it. The nation is a high form of ethnic development, so the nation is a product of a certain stage of ethnic development. The contradictory development of political processes for a long time has created an unstable situation in the field of national relations, has strengthened national indifference, indigestion and national arrogance [1]. 
Ethnic extremism is another common form of violence as a source of danger to the country's security, territorial integrity, as well as society and the state.

Ethnic extremism places its deepest traces not only in the areas where it occurs, but also in the lives of its people. As the problem is not resolved on a global scale, millions of people will suffer and history will be rich in these pages. The separatist movements who perceive the right of self-determination of nations as the main source of information are questioned not only in the regions they cover, but also the territorial integrity of states all over the world. Confidence in peoples' solidarity shakes and becomes a global problem that seriously threatens peace, stability and security [7, p. 84-97].

It is worth mentioning that unresolved conflicts in modern times create favorable conditions for ethnic extremism. Ethnic extremism is one of the factors that adversely affect the international security balance, regardless of its form and level. Ethnic extremism trends that took place in different periods of history have sometimes led to smaller - local wars and sometimes even interethnic clashes. For example, historical experience is that some empires are fragmented by ethnic extremism, i.e. separatist tendencies.

Ethnic extremism actually acted as a destructive force in the history of a number of nations. Ethnic extremism is an activity that is a source of danger to a country's national security by undermining the fundamental foundations of the state and society in an illegal way. Ethnic extremism, on the one hand, comes from the idea of 'self-determination of peoples' on the one hand, and, on the other hand, creates a real basis for the establishment of interethnic and inter-state conflicts in the international arena by violating the principles of sovereignty, territorial integrity, inviolability of the generally recognized states. Sometimes gross violations of religious and national minorities, human beings and nations accelerate the ignition of the separatist core and play an important role in the emergence of new, young nationalities. Today, in the first decades of the twenty- 
first century, separatism tendencies have also developed (Canada, Spain, etc.) and have created serious problems for developing countries (India, Pakistan, Iraq and African states) [2, p. 90].

Ethnic extremism in the political process of a country is mainly divided into two main groups. The first group includes the processes taking place in the society and the state and the country-wide factors. The second group includes regional and ethnic factors.

Thus, the first group is based on the facts of the crisis of the country system and the instability of the developing public relations over a long period of time. The second aspect of the regional aspect is economic considerations. The first is the existence of a substantial material base in resource allocation in some areas and their redistribution through transition.

Another example of the geo-economic indicators of ethnic extremism is the aggravation of the relationships between peoples of different nationalities, the main reason for which is the distribution of land plots and redistribution of collective farm ownership. Solving such problems, as a rule, leads to the separation of ethnic areas and individual autonomy.

Throughout history, personalities, ideologies, inter-class, political, social, and so on. Serious conflicts have taken place. One of these conflicts is ethnic conflicts. Ethnic conflicts and problems generally arise as a concrete manifestation of social contradictions. These conflicts are usually within a certain country [4, p. 19-25].

Ethnic extremism is also seen as an organized force that combines and exploits people by using the fear and hatred of people. One of the most pressing forms of extremism is ethnic extremism. This form shows itself by sowing hostility among the nations and peoples, creating hostility. Expressing its own nation's interests, it does not accept the rights and freedoms of other nations.

Nationalist extremism is directly related to separatism (separatism is a French word separate, separately). It focuses on the dissolution of multinational nations, 
the supreme power of the indigenous nation. One of the forms of extremism in the world is so nationalist extremism. Nationalist extremism occurs during the use of unlawful violence against another nation. Nationalist ideology is based on the description of the enemy, who represents another nation, including extremism, economic independence, culture, national values, and the cleansing of the national language. This form shows itself by sowing hostility among the nations and peoples, creating hostility.

In analyzing the characteristics of ethnic extremism, it is necessary to first define the concept of 'ethnos'. Ethnos is the narrative of the history of people who speak the same language, which has a relative constant characteristic and psychic, and that evokes their virtuosity from other groups of people [6]. Ethnic members are said to be motivated by ethnic intentions toward their own group intentions. This is also an ethnonym, naming the selfish self. Ethnos is a very complex social system. Intercultural intercourse can be in many different forms until the acculturation (partial acquisition of one's culture by another ethnicity) and assimilation (melting of one ethnos in the other).

Ethnic and inter-ethnic processes can have unifying (ethno-integration) and separation (ethnic differences and parsing). In this case ethnic tensions and open conflicts are possible.

What is the main characteristic of ethnos? In every human being, it is a matter of union with one another - family, generations, profession, etc. There is a basic need for affiliation. The most important of these demands is ethnic identity [2, p. 75].

Unlike other social associations, ethnic communities are more stable (territorial, occupational, educational, etc.). Every ethnic group believes that it can protect its culture, traditional household and spiritual unity only by creating its own state. As a driving force of the ethnos, self-defense and self-preservation of its values and traditions are required. This is his strength. At the same time, the idea 
of 'every single ethnic-one state' is utopia. The desire of each minority ethnic group to create a state can result in numerous and long-term ethnic conflicts.

Historically different nations, minorities, national minorities and ethnic groups have lived and worked in Azerbaijan. They are still living in this area today. Historical experience shows that. There has been no discrimination against any nation in Azerbaijan. Therefore, none of the ethnos living here considers itself as an alien, and does not object to others. Only Armenians. Different ethnic groups that have been settled in Azerbaijan have common features and connective characteristics that have always been dominated by the distinctive features and qualities inherent to ethnic groups. Territory generality, religious unity, material and spiritual culture proximity, combined lifestyle is factors that prevent ethnic confrontation in Azerbaijan and promote the idea of a single Homeland. The Azerbaijani language has become the means of communication of all ethnic groups living in this area and has played the role of national language.

That is why the Great Russian thinkers M. Lermontov, Bestuzhev Marlinski compared the Azerbaijani language in the 19th century with the role of the French language in Europe in the Middle East and in the Caucasus. As we have seen, these factors, shaping ethnos and ensuring their existence and survival, have historically created a real objective ground for conflict in Azerbaijan, more unity than solidarity and solidarity. We do not intend to put an end to one of the main traits of the ethnos - ethnic identity. Simply, we want to say that thanks to common traits, connecting qualities, and a sense of identity, the leading people in Azerbaijan has never been discriminated against, or hostile to ethnic groups, minorities [2].

As a result, it is important to note that the prevention of ethnic extremism, protection of our citizens against external influences and the security of the population are important issues. There are thousands of people around the world. If in modern times every nation demands independent management, it will cause chaos in this world. Because there are people in different countries, religions, 
races, nationalities. Therefore, ensuring the territorial integrity and sovereignty of states should be taken as a basis.

\section{References}

1. Agayev I. Muasir sheraitde Azerbaycanda milli-etnik prosesler [Nationaletnic processes in Azerbaijan in modern conditions]. Baku, 2006, 180 p.

2. Nuruzade Sh. Etnik munaqishele [Ethnic conflicts]. Textbook. Baku, 2015, $132 \mathrm{p}$.

3. Verdiyeva H.Yu. Pereselencheskaya politika Rossiiskoi imperii v Severnom Azerbaijane v 19-nachale $20 \mathrm{vv}$. [Resettlement policy of the Russian Impire in the Nothern Azerbaijan in 19 - at the beginning of 20 century]. Baku, 1999, 298 p.

4. Topolnitska M.I. Etnichnyi konflikt yak chinnyk rozpadu derzhavy (na prykladi Yugoslavii) [Ethnic conflict as a factor of states' destruction (on sample of Yugoslavia)]. Almanakh mizhnarodnogo prava [Almanach of International Law]. No. 20, 2018, pp. 19-25.

5. https://az.trend.az/azerbaijan/politics/2727982.html

6. https://az.wikipedia.org/wiki/Etnos

7. Hoff W. The Immigration Crisis: A Stress Test of the European Legal Culture. DOI: 10.7206/kp.2080-1084.175 / The Critique of Law. Independent Legal Studies. 2018; 10 (1), pp. 84-97 